\title{
ФОРМУВАННЯ НОВІТНІХ ЧИННИКІВ РОЗВИТКУ ТУРИСТИЧНОЇ ГАЛУЗІ В УМОВАХ ПАНДЕМІЇ
}

\section{LATEST FACTORS FORMATION OF TOURIST INDUSTRIES DEVELOPMENT IN THE PANDEMIC CONDITIONS}

\author{
Гавдей Світлана Володимирівна \\ аспірантка, \\ ДВНЗ «Прикарпатський національний університет \\ імені Василя Стефраника» \\ ORCID: https://orcid.org/0000-0002-5639-5625
}

\author{
Havdei Svitlana \\ Vasyl Stefanyk Precarpathian National University
}

\begin{abstract}
Стаття присвячена дослідженню традиційних для регіону та новітніх, пов'язаних з пандемією, чинників розвитку туристичної галузі. Проаналізовано традиційні (привабливість, розташування, інфраструктура, послуги, доступність, ціна) та регіональні (організація, фрінанси, самоврядування, знання, вміння) чинники розвитку туристичного сектору. Сфрормовано сукупність чинників, які характеризують пандемічні умови срункціонування туристичної галузі. До них віднесено медикалізацію, стійкість системи охорони здоров'я, сек'юритизацію (безпеку), поінформованість. Розроблено модель формування новітніх чинників розвитку туристичної галузі та. Запропоновано в якості суб'єкта туристичної галузі розглядати єдиний туристичний кластер. Окреслено післяепідемічні наслідки зміни усіх чинників розвитку туристичної галузі.

Ключові слова: туристична галузь, пандемія, COVID-19, чинники розвитку туристичної галузі, туристичний кластер.

Статья посвящена исследованию традиционных для региона и новейших, связанных с пандемией, фракторов развития туристической отрасли. Проанализированы традиционные (привлекательность, расположение, инфраструктура, услуги, доступность, цена) и региональные (организация, фринансы, самоуправление, знания, умения) фракторы развития туристического сектора. Сфрормирована совокупность фракторов, характеризующих пандемические условия функционирования туристической отрасли. К ним отнесены медикализация, устойчивость системы здравоохранения, секьюритизация (безопасность), осведомленность. Разработана модель формирования новейших факторов развития туристической отрасли. Предложено в качестве субъекта туристической отрасли рассматривать единый туристический кластер. Определены послеэпидемические последствия изменения всех фоакторов развития туристической отрасли.
\end{abstract}

Ключевые слова: туристическая отрасль, пандемия, COVID-19, фракторы развития туристической отрасли, туристический кластер.

In today's world, the tourism industry is a sector that generates income for millions of people and allows billions to learn more about their own and other cultures, as well as the world around them. At the same time, the tourism industry is currently the most affected by the COVID-19 pandemic, which in turn has affected both the global and many regional economies. Therefore, the search for ways out of the tourism industry from the phase of potential bankruptcy is becoming a priority not only for tourism itself, but also for the governments of many countries. Factors analysis of tourism industries development in a pandemic is just beginning. However, there is no complete answer to the study of all development factors of the tourism industry in these conditions, as well as the definition of post-epidemic consequences. The aim of the article is to study the traditional for the region and the latest pandemic-related factors in the development of the tourism industry, as well as to establish the post-epidemic consequences of changes in each of them. Traditional (attractiveness, location, infrastructure, services, affordability, price) and regional (organization, finance, self-government, knowledge, skills) development factors of the tourism sector are analyzed. A set of factors that characterize the pandemic conditions of the tourism industry has been formed. There are include medicalization, sustainability of the health care system, securitization (security), and awareness. The model of formation of the newest factors of development of tourist branch is developed. It is proposed to consider a single tourism cluster as a subject of the tourism industry. This approach will help strengthen the competitive position not only of the tourism 
industry, but, as a result, the region. The post-epidemic consequences of changes in all factors of development of the tourism industry are outlined. It is noted that "post-epidemic" influences often cannot be attributed to any one group of factors, because they have an integrated nature of influence. On the other hand, their classification will allow in the future a clearer approach to the formation of economic, legal, institutional mechanisms of settlement of the post-epidemic situation in the field of tourism.

Keywords: tourism industry, pandemic, COVID-19, factors of tourism industry development, tourism cluster.

Постановка проблеми. В сучасному світі туристична галузь є тим сектором, який формує доходів мільйонів людей і дозволяє мільярдам більше дізнатись про власну та інші культури, а також навколишній світ. Деякі країни визнають туристичну галузь провідною і визначальною для своєї економіки, оскільки вона дає близько п'ятої а то й більше частини ВВП. 3 іншого боку, туризм $€$ третім за величиною експортним сектором у світовій економіці.

В той же час туристична галузь наразі $\epsilon$ найбільш ураженою пандемією COVID-19, що, в свою чергу, вплинуло як на світову, так і на багато регіональних економік. Тому пошук шляхів виходу туристичної галузі із фрази потенційного банкрутства стає пріоритетним завданням не тільки для самого туризму, але й для урядів багатьох країн.

Аналіз останніх досліджень і публікацій. Аналіз фракторів розвитку туристичної галузі в умовах пандемії тільки починає проводитись, зокрема, цю проблему вже досліджено в працях таких вчених, як Арістейду О. [3], Бєляєва С.С. [1], Бишовець Л.Г., Куракін О.Б., Ніколюк О.В. [2], Петрів І.М., Хаустова В.Є.

Виділення невирішених раніше частин загальної проблеми. Втім, повної відповіді на дослідження всіх чинників розвитку туристичної галузі в зазначених умовах, а також визначення післяепідемічних наслідків поки що немає.

Формулювання цілей статті. Метою статті $€$ дослідження традиційних для регіону та новітніх, пов'язаних з пандемією, чинників розвитку туристичної галузі, а також встановлення післяепідемічних наслідків зміни кожного з них.

Виклад основного матеріалу дослідження. Отже, визначення традиційних та новітніх чинників розвитку туристичної галузі 3 позицій її регіональної інтерпретації та впливу пандемічних умов $€$ основою подальшого дослідження. Складність в однозначному трактуванні чинників розвитку туристичних регіонів виникає 3 необхідності врахування міждисциплінарних підходів. Це не означає абстрагування від традиційних складових туристичного продукту регіону, що фрормують його конкурентний туристичний потенціал. Традиційними серед них є:
- привабливість та розташування туристичного регіону;

- інфрраструктура та спектр послуг туристичного регіону;

- доступність туристичних послуг;

- ціновий чинник.

Прийняття новітніх чинників, пов'язаних з поширенням COVID-19, змушує по-іншому поглянути на ці складові - 3 точки зору відповіді на питання: як срормувати конкурентну перевагу туристичного регіону довготривалої перспективи шляхом врахування пандемічної ситуації, побудови нової інформаційної інорраструктури, інституційних умов та системи інновацій?

Перш ніж розглядати новітні чинники та наслідки їх впливу на розвиток туристичної галузі, варто з'ясувати причини їх появи. Як зазначено в [4], до основних причин, що зумовили дану ситуацію, можна віднести: збільшення кількості закордонних подорожей у світі, збільшення економічної міграції та економічне зростання окремих країн та регіонів. Такі процеси стали основною рушійною силою, в тому числі, для інтенсивного поширення інфекційних хвороб, що становлять загрозу для міжнародного здоров'я. На даний час у світі спостерігаються наслідки розвитку пандемії, особливо, якщо ігнорувати ранні просрілактичні дії.

Тому в [4] наголошено на фрормуванні сукупності новітніх детермінант впливу на туристичну галузь в умовах пандемії. До них віднесено:

- стійкість систем охорони здоров'я до швидкого зростання кількості людей, які потребують інтенсивної терапії;

- медикалізацію, яка спрямована на визначення соціальних проблем за категоріями хвороби [5];

- сек'юритизацію, що має на меті інтегрувати нові явища навколо категорії безпеки [6];

- поінформованість про традиційні практики з охорони здоров'я в пунктах подорожей, а також про рівень безпеки таких подорожей.

Поява нового етапу дослідження традиційних та новітніх чинників розвитку туристичної галузі нашої країни спричинена ще й через переконання про те, що останнім часом відбулось багато змін як у сфері організаційнофрінансової підтримки, так і в можливості 
активізації регіональних одиниць самоврядування, зокрема, у створенні регіонального потенціалу знань та вмінь [7]. Таким чином, пропонується модель формування новітніх чинників розвитку туристичної галузі регіону, логічна схема якої наведена на рис. 1.

Суб'єктну структуру запропонованої моделі формують усі суб'єкти, які виробляють туристичні продукти певного регіону [7]:

- туристичні підприємства;

- адміністративні одиниці самоврядування та уряду;

- суб'єкти бізнес-середовища;

- місцева громада.

Часто суб'єкти туристичної галузі виступають як єдиний туристичний кластер. Такий підхід сприяє зміцненню конкурентної позиції не тільки туристичної галузі, але, як результат, і регіону. В умовах впливу новітніх чинників, розширених за рахунок врахування пандемічних умов фрункціонування туризму, фрормування туристичних кластерних одиниць забезпечить:

- зміцнення та вдосконалення співпраці між галузевими суб'єктами (особливо це стосується співпраці галузей медицини, страхування та туризму);

- вдосконалення технологічних компетенцій, пов'язаних з присутністю дослідницьких та таких, які стосуються розвитку, організацій у рамках утворення кластерів (в тому числі розширення поінформованості як місцевої спільноти, так, і туристів про пандемічні умови задля запобігання випадків типу Нові Санжари);

- мережеву інтеграцію 3 клієнтами, надавачами туристичних послуг, субпідрядниками і постачальниками з використанням елементів сек'юритизації;
- включення галузевих суб'єктів до транснаціональних мереж, що дасть можливість доступу до нових ринків, нових можливостей, підтримку мобільності працівників в межах кластерів.

В контексті дослідження новітніх чинників розвитку туристичної галузі важливим $€$ не тільки їх визначення, але і встановлення наслідків впливу пандемії на усі групи детермінант, так званих «постепідемічних» впливів. Розглянемо їх за групами чинників, окресленими в запропонованій моделі. Отже,

1. Традиційні чинники:

Банкрутство ресторанів, кафре, барів ma інших закусочних або зміна їх власників. Подекуди це спричинено різкими обмеженнями під час пандемії при практично відсутній підтримці підприємців у цьому секторі з боку держави, в інших випадках - неможливістю утримувати приміщення та платити заробітну плату працівникам через тривалу відсутність споживачів-туристів, які досі становили домінуючий відсоток споживачів. Таку долю поділять багато закладів харчування у містах та регіонах, де туризм породжує більшість послуг у цьому секторі, особливо там, де доходи місцевих жителів занадто низькі, щоб користуватися цими послугами.

Закриття готелів та інших закладів розмімення (або відмова власників від надання послуг розміщення) може набути масового характеру, причому більше, ніж у секторі громадського харчування, оскільки заклади такого типу та розміру не можуть бути використані для інших цілей без серйозних інвестицій та реструктуризації. Найстійкішими будуть, мабуть, приватні, маленькі пансіонати, зеле-

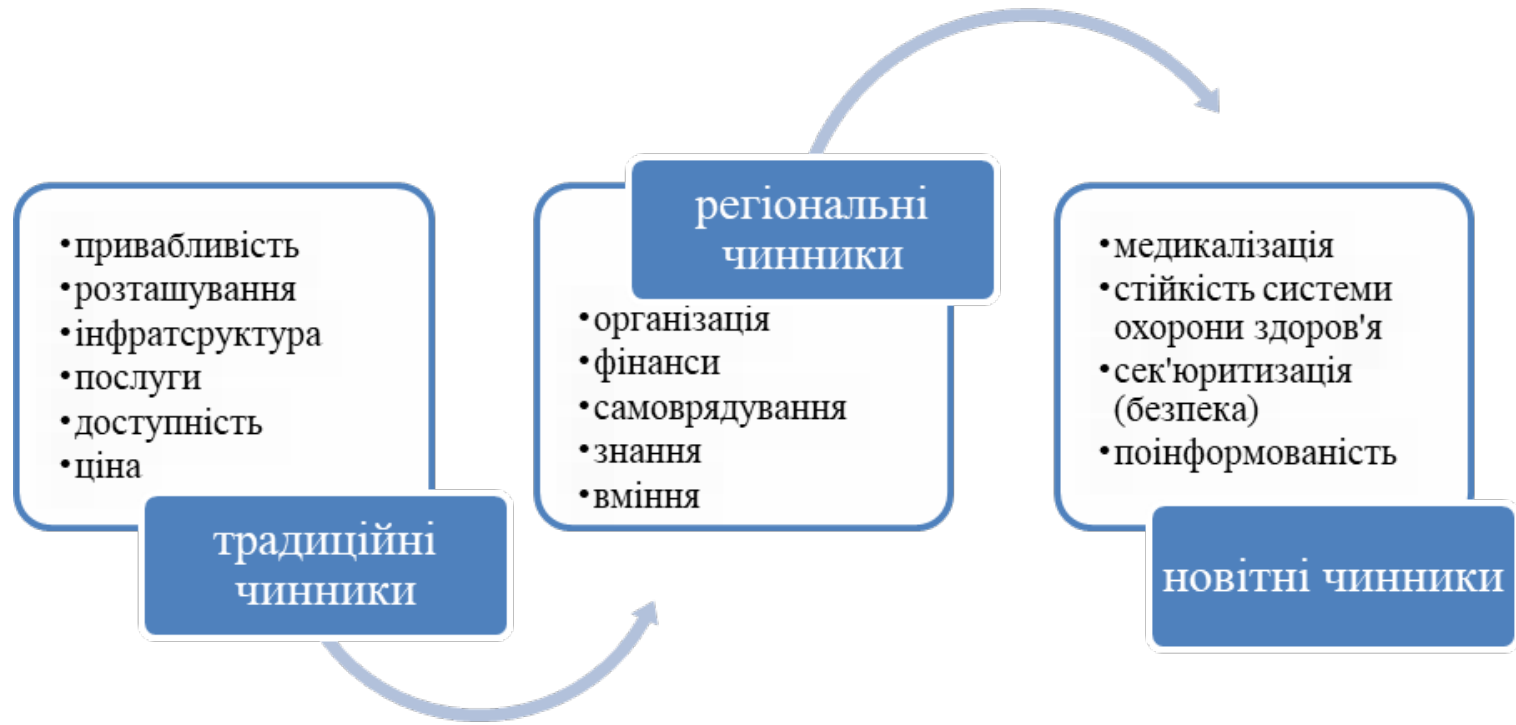

Рис. 1. Модель формування новітніх чинників розвитку туристичної галузі 
ний туризм та гостьові кімнати, власники яких зосередяться на інших заходах, і як тільки пандемія зупиниться, вони зможуть відтворити туристичне джерело доходу.

Зміни попиту. Наслідком пандемії очевидно $є$ різке зниження чисельності зовнішніх туристів, тому в після пандемічний період очікується зростання попиту на внутрішній туризм у багатьох країнах. Це тому, що багато туристів розглядатимуть можливість подорожі авіа, автомобільним, морським, залізничним або автобусним транспортом (а вони, як відомо, складають більшість видів подорожей до зарубіжних регіонів) як потенційний ризик зараження інфрекцією в скупченнях людей протягом тривалого періоду часу.

Додатково фрормується ціла сукупність фракторів, які знижують потенційний попит для зовнішнього туризму. Це і проблеми 3 відсутністю інформації про фрактичну епідеміологічну ситуацію в іншій країні, і незнання умов доступу до медичних послуг та їх рівня, і невизначеність їх отримання для іноземців.

Ставлення населення, включаючи зацікавлені в активному туризмі сторони. В умовах пандемії місцеве населення докорінно змінює своє ставлення до туристів, вважаючи їх винними в імпорті вірусу (на зразок Нових Санжар). Це явище носить тривалий характер і може впливати всупереч бажанням регіональних туристичних агентів перезапустити послуги обслуговування туристів навіть у регіонах, де надходження від них становлять значну кількість частину доходів. Це притаманно і малим туристичним агентам, які навіть діючи на користь туристів, побоюються за власну та сімейну безпеку, і ці побоювання сильніші, допоки відсутність доходу становитиме меншу загрозу, ніж голод. Для більш тривалого періоду результатом розуміння ролі туризму в економічному та культурному житті населення стане поступове «сприйняття» та «прийняття» пандемічних умов та ризиків, які вони несуть для місцевого населення.

\section{2. Регіональні чинники:}

Економічні ефекти для індустрії туризму. Одним з них буде хвиля банкрутств або припинення діяльності туристичних агентств. Можна припустити, що у секторі спеціалізованих туроператорів ця небезпека дещо менша, ніж у великих туроператорів. Це пов'язано з малим масштабом цих суб'єктів підприємництва (рідші поїздки, менше груп, рідші масштабні і навіть сезонні замовлення 3 передоплатою) та відносно високим рівнем лояльності своїх численних клієнтів, які в цій групі суб'єктів складають відносно великий відсоток учасників туризму. Такі туристи частіше приймають рішення про відтермінування поїздки.

Різке падіння доходів місцевих бюджетів, особливо там, де туризм був основним їх джерелом. Окрім регіонів, відомих своєю пропозицією рекреаційного (приморський, гірський) або оздоровчого (санаторно-курортні комплекси) туризму, особливо вразливими регіонами $є$ дестинації культурного туризму - невеликі містечка (Ронда, Ротенбург-на-Таубері, Каркассон або Масса Мариттіма) та не зовсім маленькі (Венеція, Піза, Кордова) та менш урбанізовані регіони (екомузей Бергслаген, Грецький Пелопоннес, Сардинія), які мають особливо високі ризики банкрутства в умовах пандемії. У той час як у розвинених країнах вони, ймовірно, можуть розраховувати на потужну та швидку підтримку центральних урядів, то в бідніших та погано керованих країнах довготривала криза може спричинити міграцію значної частини місцевих жителів та підприємців. Великі міста з іншими галузями економіки можуть впоратись 3 пандемічними умовами швидше. 3 іншого боку, у таких місцях (Барселона, Прага, Краків, Львів) рівень доходів від туризму буде знижуватися, стане відсутнім явище «надтуризму» та з'явиться та набуде особливого розквіту явище джентрифрікації історичних районів.

Зміни в стратегіях та організації пропозиції різних видів туристичного продукту менеджерами туристичної галузі, які будуть діяти відповідно до зміни попиту та здатності власної компанії фрункціонувати в нових для неї умовах, спрямованих, перш за все, на зменшення витрат. Болісний урок 2020 року значно прискорить впровадження автоматизованих процесів управління, що не вимагають людського персоналу: проведення консультацій за допомогою ботів, автоматизовані послуги бронювання та цілі платорорми управління подорожами, безособове обслуговування деяких визначних пам'яток за допомогою цілодобових дисплеїв, моніторинг за допомогою камер послуг розміщення, наприклад, самообслуговування в хостелах та квартирах для короткострокової оренди. Можна припустити, що у випадку закордонних подорожей, більш привабливим стануть такі види туризму, як творчий туризм, подієвий туризм, де досвід туристів базується більше на ідеях, ніж на природі, кліматичних або матеріальних антропогенних цінностях.

Зміни в напрямках та сорерах досліджень у галузі туризму. Зрозуміло, що наукова 
презентація впливу пандемії на усі галузі, в тому числі й туристичну, а також її глобальний характер переорієнтовують інтереси більшості науковців в напрямку дискусії щодо впливу цього на явища на сучасний світ. Одним з таких перших наукових дискурсів є міжнародна наукова платформа TriNet. Серед явищ, вже проаналізованих на цій платорормі, $€$ і необхідність створення моделей туризму в ситуації вимушеної соціальної дистанції; і необхідність розробки більш стійких концепцій просторових регіональних продуктів, що забезпечують та безпосередньо підтримують безпеку фрункціонування невеликих місцевих постачальників туристичних послуг, які становлять ядро творення цих продуктів та захист їх від ризику банкрутства і закриття; і необхідність врахування фракторів безпеки та охорони здоров'я в пунктах призначення та їх маркетингу, в необхідності дидактики туризму в університетах; і необхідність переосмислення переваг та недоліків туризму для місцевих громад та інших зацікавлених сторін.

3. Новітні чинники:

Зміни в політиці безпеки та охорони здоров'я 3 боку влади. Вони стосуються виконання цілком раціональних правил безпеки (сек'юритизації), наприклад, виконання обмежень щодо обсягу засідань, пересування великих груп людей та багатосторонніх зустрічей. В той же час мають місце не завжди ефрективні дії в надзвичайних ситуаціях, наприклад, закриття кордонів країн 3 подібною картиною зараження без аналізу фактичного шляху поширення вірусу. Такі правила містять десятки тисяч винятків (як-от для водіїв, які здійснюють міжнародні перевезення, та звільнені від будь-якого карантину) і одночасно створюють штучний натовп на прикордонних пунктах та в аеропортах, що, навпаки, сприяє прискореному зараженню людей, змушених збиратися в таких місцях. Такі раціональні правила (окрім неефективних випадків) розраховані на тривалий час дії.

Зміни у ставленні та споживчій поведінці туристів. Тут варто відштовхуватись від видів туризму, які виокремлюють різні чинники при прийнятті рішень щодо туристичної поведінки споживачів:

- об'єктивно-індивідуальні чинники - це можливості конкретного споживача туристичного продукту, такі як: тривалість його відпустки або вільний час, його поточний стан доходів, фрізичний стан, здоров'я та сімейні зобов'язання;
- економічні чинники, які включають: ціну туристичного продукту та суб'єктивність їі сприйняття споживачем (незалежно від того, оцінює він це як дорого чи як економічно вигідно), фрактичну купівельну спроможність замовника та курси валют, що її фрормують (сприятливі для придбання туристичного продукту, реалізованого за кордоном), ціну пропозиції конкурентів та її оцінку самим клієнтом;

- мотиваційні чинники - це особистий рівень готовності/рішучості до подорожі загалом та подорожувати до певного регіону/ місця. На них, серед іншого, впливають інтереси клієнтів, сорормовані їх отриманим рівнем освіти та інтелектуальними горизонтами, диверсифікацією способів отримання нових знань, улюбленими культурними, рекреаційними, творчими заходами, хобі, пристрастями, звичками. Не менш важливими мотиваційними чинниками для клієнта є вплив членів сім'ї, засобів масової інфоомації та навколишнього середовища, особистих, сімейних, етнічних, релігійних та інших зв'язків з місцем подорожі, а також попередній досвід подібних подорожей (так звана біографрія туриста) та багато інших фракторів;

- оцінка безпеки та ризику - значення цієї групи оракторів в аналізованій ситуації однозначно збільшується та впливає на остаточне рішення клієнта.

Варто зауважити, що вказані «постепідемічні» впливи часто не можна віднести до якоїсь однієї групи чинників, тому що вони мають інтегрований характер впливу. 3 іншого боку, така їх класифікація дозволить в майбутньому чіткіше підійти до формування економічних, правових, інституційних меланізмів врегулювання післяепідемічної ситуації в галузі туризму.

Висновки. Таким чином, в статті розглянуто традиційні для туристичної галузі чинники, регіональні детермінанти розвитку туризму, а також новітні, пов'язані з пандемічними умовами фрункціонування. Встановлено, що наявні пандемічні умови, звичайно, тільки посилять вплив рівня медицини на розвиток туризму та ставлять аспекти здоров'я та безпеки подорожей в центр уваги як для туристів, так і для громад, які їх приймають. Тому розроблена модель фрормування новітніх чинників розвитку туристичної галузі покликана врахувати такі особливі для галузі туризму чинники, як медикалізація та сек'юритизація, поінформованість нарівні з традиційними для цієї галузі детермінантами. Окреслено післяепідемічні наслідки зміни усіх чинників розвитку туристичної галузі. 


\section{СПИСОК ВИКОРИСТАНИХ ДЖЕРЕЛ:}

1. Бєляєва С.С., Куракін О.Б., Бишовець Л.Г. Організаційно-економічні аспекти якості послуг готелів і закладів розміщення під час пандемії на COVID-19. Збірник наукових праць чдтУ. Серія Економіка. 2020. Вип. 57. С. 54-63.

2. Ніколюк О.В., Хаустова В.Є., Петрів І.М. Державне регулювання розвитку сільського зеленого туризму в умовах пандемії COVID-19. Наукові записки Iнституту законодавства ВРУ. 2020. № 5. C. 119-127.

3. Aristeidou O. EBRD and UNWTO boost tourism recovery. European Bank for Reconstruction and Development. 26 June 2020. Available at https://www.ebrd.com/news/2020/ebrd-and-unwto-boost-tourism-recovery.html

4. Гавдей С.В. Особливості розвитку туристичної галузі в умовах пандемії. Science and Global Studies: тези доповідей V Міжнародної наукової конференції. Прага, Чехія. 30 грудня 2020. URL: https://www.inter-nauka.com/ uploads/public/16108281191418.pdf

5. Conrad P. Medicalization and social control. Annual Review of Sociology. 1992. Vol. 18. № 1. P. 209-232.

6. Buzan B., Waver O. Macrosecuritisation and security constellations: reconsidering scale in securitisation theory. Review of International Studies. 2009. Vol. 35. № 2. P. 253-276.

7. Дмитришин Л.І., Павлюк Т.Д. Методичні основи дослідження факторів конкурентоспроможності туристичного бізнесу в регіонах. Вісник Чернівецького торговельно-економічного інституту. Економічні науки. 2014. Вип. 4(56). С. 112-119.

\section{REFERENCES:}

1. Bieliaieva S.S., Kurakin O.B., Byshovets L.H. (2020) Orhanizatsiino-ekonomichni aspekty yakosti posluh hoteliv i zakladiv rozmishchennia pid chas pandemii na COVID-19 [Organizational and economic aspects of the quality of services of hotels and accommodation facilities during the pandemic at COVID-19]. Zbirnyk naukovykh prats ChDTU. Seriia Ekonomika, vol. 57, pp. 54-63. (in Ukrainian)

2. Nikoliuk O.V., Khaustova V.le., Petriv I.M. (2020) Derzhavne rehuliuvannia rozvytku silskoho zelenoho turyzmu v umovakh pandemii COVID-19 [State regulation of rural green tourism development in the context of the COVID-19 pandemic]. Naukovi zapysky Instytutu zakonodavstva VRU, no. 5, pp. 119-127. (in Ukrainian)

3. Aristeidou O. (2020) EBRD and UNWTO boost tourism recovery. European Bank for Reconstruction and Development. 26 June 2020. Available at: https://www.ebrd.com/news/2020/ebrd-and-unwto-boost-tourism-recovery.html

4. Havdei S.V. (2020) Osoblyvosti rozvytku turystychnoi haluzi v umovakh pandemii [Features of the tourism industry in a pandemic]. Science and Global Studies: tezy dopovidei V Mizhnarodnoi naukovoi konferentsii. Praha, Chekhiia. 30 hrudnia 2020. URL: https://www.inter-nauka.com/uploads/public/16108281191418.pdf (in Ukrainian)

5. Conrad P. (1992) Medicalization and social control. Annual Review of Sociology, vol. 18, no. 1, pp. 209-232.

6. Buzan B., Waver O. (2009) Macrosecuritisation and security constellations: reconsidering scale in securitisation theory. Review of International Studies, vol. 35, no. 2, pp. 253-276.

7. Dmytryshyn L.I., Pavliuk T.D. (2014) Metodychni osnovy doslidzhennia faktoriv konkurentospromozhnosti turystychnoho biznesu $v$ rehionakh [Methodical bases of competitiveness factors research of tourist business in regions]. Visnyk Chernivetskoho torhovelno-ekonomichnoho instytutu. Ekonomichni nauky, vol. 4(56), pp. 112-119. (in Ukrainian) 